\title{
Nicotine Improves Cognitive Deficits of Dopamine Transporter Knockout Mice without Long-Term Tolerance
}

\author{
Stéphanie Weiss', Marika Nosten-Bertrand', J Michael Mclntosh², Bruno Giros*,' \\ and Marie-Pascale Martres' \\ IInserm, U5 I3, Laboratoire de Neurobiologie et Psychiatrie, University Paris 12, Créteil, France; ${ }^{2}$ Department of Psychiatry, University of Utah, \\ Salt Lake City, UT, USA
}

\begin{abstract}
Various studies suggest a dysfunction of nicotinic neurotransmission in schizophrenia and establish that patients suffering from schizophrenia and attention deficit hyperactivity disorder (ADHD) have a high tobacco consumption, potentially for the purpose of selfmedication. Owing to its neuroprotective and procognitive effects, transdermal nicotine was proposed to be an effective treatment of some neurodegenerative and psychiatric diseases. Mice deficient in the dopamine transporter (DAT KO) exhibit a phenotype reminiscent of schizophrenia and ADHD, including hyperdopaminergia, hyperactivity, paradoxical calming by methylphenidate and cognitive deficits, some of which being improved by antipsychotic agents. We recently demonstrated that nicotinic receptor content and function were profoundly modified in DAT KO mice. In this study, we assessed the effects of a chronic nicotine treatment in the drinking water on the nicotine-induced locomotion, anxiety status and learning performance. Chronically nicotine-treated DAT KO mice were always hypersensitive to the hypolocomotor effect of nicotine without tolerance and did not exhibit the anxiogenic effect of nicotine treatment observed in WT mice. Very interestingly, both acute and chronic nicotine treatments greatly improved their deficits in the cued and spatial learning, without eliciting tolerance. We speculate that the procognitive effects of nicotine in DAT KO mice are related to the upregulation of $\alpha 7$ nicotinic receptors in the hippocampus, amygdala, and prelimbic cortex, all areas involved in cognition. Data from our studies on DAT KO mice shed light on the nicotine self-medication in psychiatric patients and suggest that nicotinic agonists could favorably lead to additional therapy of psychiatric diseases.
\end{abstract}

Neuropsychopharmacology (2007) 32, 2465-2478; doi:I0.1038/sj.npp. I30I385; published online 2I March 2007

Keywords: anxiogenesis; chronic nicotine treatment; hypolocomotion; water maze; ADHD; schizophrenia

\section{INTRODUCTION}

Nicotine, as all drugs of abuse, induces dopamine (DA) release in the shell of the nucleus accumbens (Pontieri et al, 1996; for a review, see Di Chiara et al, 2004). Effects of nicotine on DAergic neurotransmission are mediated via various nicotinic/cholinergic receptor (nAChR) subtypes (for reviews, see Wonnacott, 1997; Le Novere et al, 2002) localized in dopaminergic mid and forebrain areas.

Dysfunction of nicotinic neurotransmission has been implicated in several psychiatric disorders, including schizophrenia (for a review, see Mihailescu and DruckerColin, 2000). Moreover, epidemiological data show increased tobacco intake in patients suffering from psychiatric disorders, such as schizophrenia and attention deficit hyperactivity disorder (ADHD), potentially as a form of

\footnotetext{
*Correspondence: Dr B Giros, Inserm, U5I3, Laboratoire de Neurobiologie et Psychiatrie, University Paris 12, Créteil F-94000, France, Tel: + (33) 139813 539, Fax: + (33) 139813 685,

E-mail: Bruno.Giros@creteil.inserm.fr

Received 18 May 2006; revised 25 January 2007; accepted 29 January 2007
}

auto-medication to offset disease pathophysiology (for reviews, see Mihailescu and Drucker-Colin, 2000; Sacco et al, 2004). Indeed, nicotine patches decrease depressive mood, reduce the severity of attentional deficits and improve cognitive deficits associated with schizophrenia and ADHD (Levin et al, 1996, 2001; Myers et al, 2004; Kumari and Postma, 2005; for reviews, see Rezvani and Levin, 2001; Buccafusco et al, 2005). Wilens et al (1999) reported that ABT-418, a preferential $\alpha 4 \beta 2 \mathrm{nAChR}$ agonist, can also reduce impulsivity and hyperactivity in adults with ADHD.

The inactivation of the dopamine transporter (DAT) gene, which plays a key role in the regulation of DAergic transmission, generate constitutively hyperDAergic mice (DAT KO mice, Giros et al, 1996). DAT KO mice show spontaneous hyperactivity and a paradoxical calming effect of psychostimulants, like methylphenidate used for ADHD therapy (Gainetdinov et al, 1999b; Spielewoy et al, 2001). These mice also exhibit a loss of lateralization, a deficit in pre-pulse inhibition of the startle reflex, as well as cognitive impairments, some of these being restored by antipsychotic agents (Gainetdinov et al, 1999a; Ralph et al, 2001; Morice et al, 2005; Morice et al, 2007). All these data suggest that 
DAT KO mice represent a pertinent model for some of the symptoms encountered in schizophrenia, ADHD, and drug abuse (Gainetdinov and Caron, 2000; for a review, see Gainetdinov et al, 2001). Interestingly, some human genetic studies suggest the involvement of a DAT gene polymorphism in ADHD (Cook et al, 1995; Gill et al, 1997; Waldman et al, 1998; for a review, see DiMaio et al, 2003), although recent meta-analyses do not confirm this association (Purper-Ouakil et al, 2005; Li et al, 2006). PET scan data have shown an increase of DAT density in the caudateputamen of ADHD patients, reversed by nicotine abuse (Krause et al, 2003) and by methylphenidate treatment (Krause et al, 2003; Vles et al, 2003). Furthermore, in vivo imaging studies have provided evidence for a loss of the right-left asymmetry of DAT in the caudate of schizophrenic patients (Hsiao et al, 2003).

Altogether, these data prompted us to study nicotinic neurotransmission in DAT KO mice. We recently observed that constitutive hyperDAergia elicited profound alterations in basal nAChR density and acute nicotine-induced behaviors in DAT KO mice (Weiss et al, 2007). In particular, mutant mice were hypersensitive to the hypolocomotor effect of nicotine. Interestingly, co-administration of $\beta 2^{*}$ $\left(\beta 2^{*}\right.$ receptor means its association with other nicotinic sub-units) and $\alpha 7$ nicotinic agonists at sub-active doses induced a synergistic hypolocomotor effect in mutant mice and nicotine did not elicit anxiety as in wild-type (WT) mice. In the present study, we investigated if acute nicotineinduced effects in DAT KO mice persist after chronic nicotine treatment. We chose to deliver nicotine in the drinking water, a more physiological administration mode (Pekonen et al, 1993; Pietila and Ahtee, 2000). We assessed the effects of chronic nicotine treatment on nicotineinduced locomotion and on the anxiety status of WT and DAT KO mice. Furthermore, owing to the procognitive effects of nicotine in schizophrenic and ADHD patients and in rodents (for a review, see Levin et al, 2006), we also tested the effects of both acute and chronic nicotine administrations on learning in DAT KO mice. For this purpose, we chose to test mouse performance in the cued and spatial versions of the Morris watermaze. Finally, we determined the effect of chronic nicotine treatment on the density of various DAergic and nicotinic receptors in some brain areas of WT and DAT KO mice.

\section{MATERIALS AND METHODS}

\section{Animals and Chronic Treatment by Nicotine}

The F1 hybrid WT and homozygous DAT KO mice were obtained by crossing congenic (12 backcrosses) C57BL/ 6JOrl-DAT heterozygous (HT) females with congenic (11 backcrosses) DBA/2JOrl-DAT HT males, as described previously (Morice et al, 2004). The genotype of the mice was determined by polymerase chain reaction analysis of tail biopsy DNA, according to Carboni et al (2001). Animals were housed under standard conditions, with food and water available ad libitum and a light cycle of a $12 \mathrm{~h}$ light: $12 \mathrm{~h}$ dark (lights on at $0730 \mathrm{~h}$ ). Experiments were carried out in accordance with the European Communities Council Directive (86/809/EEC) and approved by the local ethical committee.
Mice were weaned at 4 weeks and were housed 2-4 per cage by litter, gender, and genotype. Nicotine was administered for 8 weeks in the drinking water (as only source of fluid), at a concentration of $70 \mu \mathrm{g} / \mathrm{ml}$ (free base), supplemented with $2 \%$ saccharin (Pietila and Ahtee, 2000). Control mice received $2 \%$ saccharin in their drinking water. Body weight, fluid intake, and basal locomotor activity (see below) were recorded each week. All experiments were performed on naive WT and KO mice (about 60/40 females/ males) from the same litters. Mice were 10-13 weeks old at the beginning of chronic treatments.

\section{Drugs}

( \pm )-Butaclamol hydrochloride, 1,3-di-o-tolylguanidine, dopamine hydrochloride, nicotine hydrogen tartrate, and saccharin were purchased from Sigma-Aldrich (Saint Quentin Fallavier, France). Apomorphine hydrochloride and $( \pm)$-epibatidine hydrochloride were purchased from Tocris Cookson (Bristol, UK). Nicotine was dissolved in physiological saline as free base and was administered subcutaneously in a volume of $100 \mu \mathrm{l}$ per $20 \mathrm{~g}$ weight. $\left[{ }^{125} \mathrm{I}\right]-$ iodosulpride (74 TBq/mmol), (3-[ $\left.{ }^{125} \mathrm{I}\right]$-iodotyrosyl)- $\alpha$-bungarotoxin $(5.5 \mathrm{TBq} / \mathrm{mmol})$, and $\left[N\right.$-methyl $\left.{ }^{3} \mathrm{H}\right] \mathrm{SCH} 23390$ (2.2-3.3 TBq/mmol) were from GE Healthcare (Orsay, France). $\left[{ }^{125} \mathrm{I}\right]$ Epibatidine $(74 \mathrm{TBq} / \mathrm{mmol})$ and $\left[{ }^{125} \mathrm{I}\right]-\mathrm{R}(+)$ trans-7-hydroxy-2-( $N$-( $3^{\prime}$-iodo-2'-propenyl)amino $)$ tetralin $\left(\left[{ }^{125} \mathrm{I}\right]-7-\mathrm{OH}-\mathrm{PIPAT}, 74 \mathrm{TBq} / \mathrm{mmol}\right)$ were from Perkin Elmer-NEN (Orsay, France). $\left[{ }^{125} \mathrm{I}\right]-\alpha$-Conotoxin-MII was synthesized as described previously (Whiteaker et al, 2000).

\section{Behavioral Studies}

Locomotor activity. The horizontal (locomotion) and vertical (rearing) activities were assessed in transparent activity cages $(20 \times 15 \times 25 \mathrm{~cm})$, with automatic monitoring of photocell beam breaks, located at $1.5 \mathrm{~cm}$ (horizontal activity) and $6.5 \mathrm{~cm}$ (vertical activity) above the floor (Imetronic, Bordeaux, France). Basal locomotor activities of mice were recorded for $60 \mathrm{~min}$, between $1000 \mathrm{~h}$ and $1400 \mathrm{~h}$, weekly during the chronic nicotine treatment. After 8 weeks of treatment, saccharin, and nicotine were substituted with water, $24 \mathrm{~h}$ before testing the locomotor effect of $1 \mathrm{mg} / \mathrm{kg}$ nicotine.

Elevated plus maze. The Plexiglas plus maze apparatus consisted of a central platform $(7 \times 7 \mathrm{~cm})$, two open arms $(30 \times 7 \mathrm{~cm})$, and two closed arms $(30 \times 7 \mathrm{~cm})$ with $17 \mathrm{~cm}$ high walls. The maze was placed at a height of $55 \mathrm{~cm}$ above the floor and located in a 50 lux illuminated soundattenuated room. Mice were placed in the central platform and allowed to freely explore the maze for $5 \mathrm{~min}$. The numbers of entries and the time spent in both the open and closed arms were measured by two observers. The experiments were conducted between $1400 \mathrm{~h}$ and $1700 \mathrm{~h}$.

Morris watermaze. The watermaze consisted of a circular stainless-steel pool ( $150 \mathrm{~cm}$ diameter, $29 \mathrm{~cm}$ height) filled to a depth of $16 \mathrm{~cm}$ with water at $20-22^{\circ} \mathrm{C}$ and made opaque using a white aqueous emulsion (Acusol ${ }^{\circledR}$ OP 301 opacifier, Rohm Ihaas, France). The pool was located in a soundattenuated and brightly illuminated room. A video tracking 
system, including an overhead camera connected to an image analyzer and a computer (View Point, France), was used to monitor activity.

In the cued version, mice were trained to find and escape onto a rough stainless steel platform $(9 \mathrm{~cm}$ diameter) located at the water surface and made visible by blue material. The pool was surrounded by curtains to hide other spatial cues. Both the platform location and the animal starting position were pseudo-randomly changed for each trial. Trials ended when mice climbed onto the platform, with a maximum searching time of $90 \mathrm{~s}$. Mice that did not find the platform were gently guided and placed on it for 20 s. Animals were trained with two trials per day, for 5 consecutive days.

In the spatial version, the escape platform $(6 \mathrm{~cm}$ diameter $)$ was submerged $1 \mathrm{~cm}$ below the water surface. Mice learned the fixed position of the platform using prominent distal extra-maze cues arranged around the pool. The animal starting position was changed pseudo-randomly between each trial that ended when mice climbed onto the platform, with a maximum searching time of $90 \mathrm{~s}$. Mice that did not find the platform were gently guided and placed on it for $20 \mathrm{~s}$. The animals were trained with two trials per day, for 6 consecutive days. At the end of the last trial, animals were tested in the quadrant test. The platform was removed and the distance traveled by mice in each quadrant was monitored.

In the two versions, the first trials were conducted from $1000 \mathrm{~h}$, mice were then left undisturbed in their home cage before the second trials at $1400 \mathrm{~h}$. The mean latency (s), the mean distance traveled $(\mathrm{m})$, the swimming speed $(\mathrm{cm} / \mathrm{s})$ and the proportion of successful trials were measured for each mouse.

\section{Quantitative Autoradiography}

Mice were killed by cervical dislocation and their brains rapidly removed and frozen in isopentane at $-30^{\circ} \mathrm{C}$. Serial $10 \mu \mathrm{m}$ coronal sections were cut at $-20^{\circ} \mathrm{C}$, thaw-mounted on Superfrost Plus ${ }^{\circledR}$ slides and stored at $-80^{\circ} \mathrm{C}$ until use. To rule out possible binding of endogenous DA or acetylcholine to their own receptors, sections were preincubated in buffer before addition of radioactive ligands.

Autoradiographic determination of D1, D2 and D3 dopaminergic receptor densities. Labeling of D1 receptors was performed according to Fernagut et al (2003). Slides were preincubated for $20 \mathrm{~min}$ at room temperature in $50 \mathrm{mM}$ Tris- $\mathrm{HCl}$ buffer, $\mathrm{pH} \mathrm{7.4,} \mathrm{containing} 120 \mathrm{mM} \mathrm{NaCl}$, $5 \mathrm{mM} \mathrm{KCl} 2 \mathrm{mM} \mathrm{CaCl}_{2}$, and $1 \mathrm{mM} \mathrm{MgCl}_{2}$ (Tris-ions buffer). Slides were incubated for $90 \mathrm{~min}$ at room temperature in a fresh Tris-ions buffer containing $3 \mathrm{nM}\left[{ }^{3} \mathrm{H}\right]-\mathrm{SCH} 23390$, with or without $10 \mu \mathrm{M}$ butaclamol to determine non-specific binding. After four washes for $5 \mathrm{~min}$ with ice-cold Tris-ions buffer, sections were rapidly dipped in ice-cold water and dried. Slides were exposed to BAS-TR Fuji Imaging screens for 3 days and the screens were scanned with a Fuji Bioimaging Analyzer BAS-5000.

Labeling of D2 receptors was carried out according to Martres et al (1985). Slides were preincubated three times for $5 \mathrm{~min}$ at room temperature in Tris-ions buffer supplemented with $0.1 \%$ bovine serum albumin (BSA) and $0.57 \mathrm{mM}$ ascorbic acid. They were incubated for $60 \mathrm{~min}$ at room temperature in the same buffer in the presence of $0.2 \mathrm{nM}\left[{ }^{125} \mathrm{I}\right]$-iodosulpride, with or without $10 \mu \mathrm{M}$ apomorphine to determine non-specific binding. Sections were washed as described for D1 receptor labeling and exposed to Biomax MR films (GE Healthcare) for 12-36 h.

Labeling of D3 receptors was performed according to Stanwood et al (2000), with the following modifications: slides were preincubated three times for $5 \mathrm{~min}$ at room temperature in $50 \mathrm{mM}$ HEPES buffer, $\mathrm{pH} 7.4$, supplemented with $1 \mathrm{mM}$ EDTA, $2.8 \mathrm{mM}$ ascorbic acid, $0.1 \%$ BSA, $100 \mu \mathrm{M}$ GTP (to dissociate $\mathrm{D} 2$ receptors from $\mathrm{G}$ proteins) and $25 \mu \mathrm{M}$ 1,3-di-otolylguanidine (to remove the labeling of $\sigma$ receptors). Then, sections were incubated for $60 \mathrm{~min}$ at room temperature in the same buffer in the presence of $0.25 \mathrm{nM}\left[{ }^{125} \mathrm{I}\right]-7-\mathrm{OH}-$ PIPAT, with or without $10 \mu \mathrm{M}$ DA to determine non-specific binding. Sections were washed four times for $15 \mathrm{~min}$ in icecold HEPES buffer, dipped in ice-cold water, dried, and exposed to Biomax MR films for 1-3 days.

Autoradiographic determination of $\beta 2^{*}, \alpha 6^{*}\left(\alpha 6^{*}\right.$ receptor means its association with other nicotinic sub-units) and $\alpha 7$ nicotinic receptor densities. Labeling of $\beta 2^{*}$ nicotinic receptors was performed according to Perry and Kellar (1995). Slides were preincubated three times for $5 \mathrm{~min}$ at room temperature in Tris-ions buffer. Sections were incubated for $40 \mathrm{~min}$ at room temperature in the same buffer in the presence of $0.4 \mathrm{nM}\left[{ }^{125} \mathrm{I}\right]$-epibatidine, with or without $300 \mu \mathrm{M}$ nicotine to determine non-specific binding. Slides were then washed twice for $5 \mathrm{~min}$ in ice-cold Trisions buffer, dipped in ice-cold water, dried, and exposed to Biomax MR films for 2-3 days.

Labeling of $\alpha 6^{*}$ subunits was performed according to Whiteaker et al (2000). Slides were preincubated for $15 \mathrm{~min}$ at room temperature in $20 \mathrm{mM}$ HEPES buffer, $\mathrm{pH} 7.5$, containing $144 \mathrm{mM} \mathrm{NaCl}, 1.5 \mathrm{mM} \mathrm{KCl}, 2 \mathrm{mM} \mathrm{CaCl}_{2}, 1 \mathrm{mM}$ $\mathrm{MgSO}_{4}$ (standard binding buffer), supplemented with $0.1 \%$ BSA and $1 \mathrm{mM}$ phenylmethylsulfonyl fluoride. Sections were incubated for $2 \mathrm{~h}$ at room temperature in the presence of $0.8 \mathrm{nM}\left[{ }^{125} \mathrm{I}\right]-\alpha$-conotoxin-MII in standard binding buffer supplemented with $0.1 \%$ BSA, $5 \mathrm{mM}$ EDTA, $5 \mathrm{mM}$ EGTA, and $1 \mathrm{mg} / 100 \mathrm{ml}$ of aprotinin, leupeptin, and pepstatin A (protease inhibitors), with or without $1 \mu \mathrm{M}$ epibatidine to determine non-specific binding. Slides were washed for $30 \mathrm{~s}$ at room temperature and then at $4{ }^{\circ} \mathrm{C}$ in standard binding buffer plus $0.1 \%$ BSA. Afterwards, the samples were washed twice for $5 \mathrm{~s}$ at $4{ }^{\circ} \mathrm{C}$ in standard binding buffer with $0.01 \%$ BSA and, finally, twice for $5 \mathrm{~s}$ at $4^{\circ} \mathrm{C}$ in $5 \mathrm{mM}$ HEPES buffer, $\mathrm{pH}$ 7.5. After dipping in ice-cold water and drying, they were exposed to Biomax MR films for 1-3 days.

Labeling of $\alpha 7$ nicotinic receptors was performed according to Spurden et al (1997). Slides were pre-incubated for $30 \mathrm{~min}$ at room temperature in $50 \mathrm{mM}$ Tris- $\mathrm{HCl}$ buffer, $\mathrm{pH} 7.4$, containing $0.1 \%$ BSA. Sections were next incubated for $2 \mathrm{~h}$ at room temperature in the same buffer in the presence of $0.5 \mathrm{nM}\left[{ }^{125} \mathrm{I}\right]-\alpha$-bungarotoxin, with or without $1 \mathrm{mM}$ nicotine to determine non-specific binding. Slides were washed four times for $10 \mathrm{~min}$ in ice-cold Tris-HCl buffer, dipped in ice-cold water, dried, and exposed to Biomax MR films for 1 week.

Quantification of receptor density. Standard radioactive microscales (GE Healthcare) were exposed on each autoradiographic film to ensure that labeling densities were in 
the linear range. The autoradiograms were scanned and densitometry was performed with Multi Gauge software or MCID $^{\mathrm{TM}}$ Analysis software for $\left[{ }^{3} \mathrm{H}\right]-$ or $\left[{ }^{125} \mathrm{I}\right]$-radioligand, respectively. Specific labeling densities (mean gray values in arbitrary units) of four sections per area were averaged for each mouse.

\section{Statistical Analysis}

Behavioral data were subjected to factorial two-, three- or four-way ANOVA, with genotype, sex, and treatment as between-group factors and time as a within-group factor. Significant main effects were further analyzed by post hoc comparisons of means using Fisher's exact test. The numbers of successful trials in the Morris watermaze tests were compared by the Kolmogorov-Smirnov non-parametric test. Data from autoradiographic experiments were subjected to factorial one-, two-, or three-way ANOVA, with genotype, area, and treatment as between-group factors. Significant main effects were further analyzed by post hoc comparisons of means using Fisher's exact test.

\section{RESULTS}

\section{Effect of Chronic Nicotine Treatment on the Basal Locomotor Activity of WT and DAT KO Mice}

Each mouse drank about $6 \mathrm{ml}$ per $24 \mathrm{~h}$ and no significant difference was observed in the consumption of drinking water, regardless of genotype, gender, and treatment (not shown). This quantity corresponds to about $17 \mathrm{mg} / \mathrm{kg} /$ day nicotine (free base) and $5 \mathrm{~g} / \mathrm{kg} /$ day saccharin.

A significant difference of body weight between WT and DAT KO mice was observed, as reported previously (Morice et al, 2004). However, saccharin or nicotine treatment did not significantly alter mouse weight gain, whatever genotype and gender (not shown).

DAT KO mice were hyperactive, as already reported (Giros et al, 1996; Spielewoy et al, 2000; Morice et al, 2004). Whereas the basal locomotor activity of saccharin- or nicotine-treated WT mice and nicotine-treated DAT KO mice did not significantly vary during the 8-week treatment, the basal activity of saccharin-treated DAT KO mice was significantly increased by $41 \%$ between week 2 and week 8 $\left(\mathrm{F}_{1,29}=6.04, p=0.020\right.$, Figure 1$)$. The increased basal locomotor activity could be owing to higher reactivity of DAT KO mice to aging or to 8-week experimentation, including weighing, exposure to actimeter cages and/or saccharin treatment. Oral chronic nicotine treatment of WT mice significantly increased their basal locomotor activity by $+15 \%$ during treatment (treatment: $F_{1,186}=7.91$, $p=0.009$; Figure 1), probably due to behavioral sensitization and/or to withdrawal syndrome (Pietila and Ahtee, 2000; Gaddnas et al, 2001). The same chronic nicotine treatment slightly decreased, but not significantly, basal locomotor activity of DAT KO mice.

\section{Absence of Tolerance to Nicotine-Induced Hypolocomotion in Nicotine-Treated DAT KO Mice}

We recently showed that DAT KO mice were hypersensitive to acute $1 \mathrm{mg} / \mathrm{kg}$ nicotine-induced hypolocomotion (Weiss

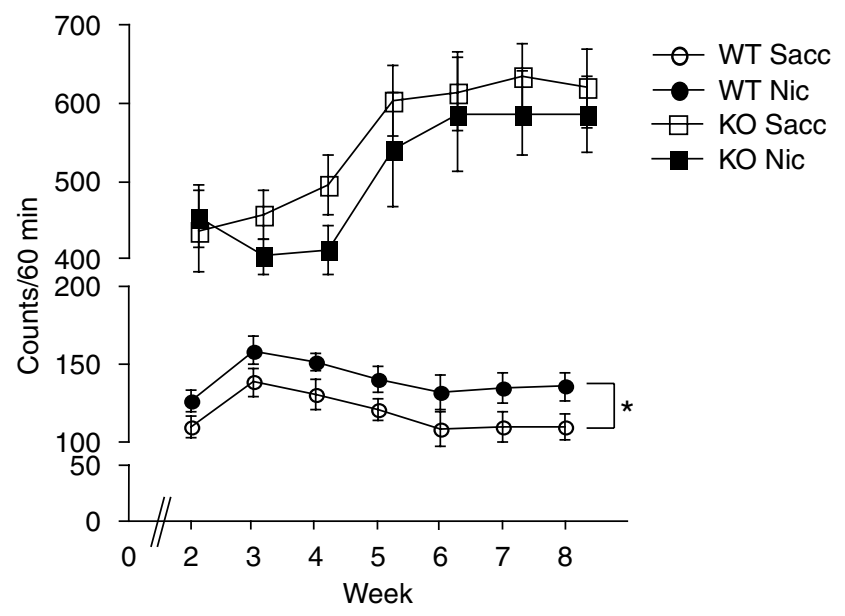

Figure I Effect of chronic nicotine administration in the drinking water on the basal locomotor activity of WT and DAT KO mice. Time course of basal horizontal locomotor activity of wild-type (WT, circles) and DAT KO (KO, squares) mice during the 8-week saccharin (Sacc) or nicotine (Nic) treatment. Means \pm SEM of photocell counts over a $60 \mathrm{~min}$ period for I5-16 mice per group. Fisher's test: $* 0<0.05$, comparison with saccharintreated mice.

et al, 2007). In the present study, we determined the responsiveness of WT and DAT KO mice to $1 \mathrm{mg} / \mathrm{kg}$ nicotine, after an 8-week saccharin or nicotine treatment followed by a $24 \mathrm{~h}$ withdrawal (Figure 2). Statistical analysis of data showed a significant effect of genotype, treatment, and time (genotype: $F_{1,1001}=196.21, p<0.001$; treatment: $\mathrm{F}_{3,1001}=17.84, \quad p<0.001 ;$ genotype $\times$ treatment: $\mathrm{F}_{3,1001}=$ 13.09, $\quad p<0.001$; genotype $\times$ treatment $\times$ time: $\mathrm{F}_{33,1001}=$ 7.98, $p<0.001)$. DAT KO mice exhibited higher basal locomotor activity than WT mice and no habituation during the $60 \mathrm{~min}$ monitoring (genotype: $\mathrm{F}_{1,253}=58.68, p<0.001$; genotype $\times$ time: $\left.\mathrm{F}_{11,253}=6.80, \quad p<0.001\right), \quad$ as reported previously (Giros et al, 1996; Spielewoy et al, 2000; Morice et al, 2004).

Chronic nicotine treatment elicited a significant $37 \%$ increase of the basal activity of WT mice over the time course (compare Sacc-Sal with Nic-Sal, treatment: $\mathrm{F}_{1,385}=4.24, p=0.047$; Figure 2). This increased basal hyperactivity was reminiscent of the withdrawal syndrome described previously in mice after such treatment (Pietila and Ahtee, 2000; Gaddnas et al, 2001). In contrast, chronic nicotine treatment had no significant effect on the basal locomotion of DAT KO (Figure 2).

WT mice chronically treated by nicotine were tolerant to the hypolocomotion induced by the challenge dose of nicotine. Indeed, $1 \mathrm{mg} / \mathrm{kg}$ nicotine inhibited the locomotor activity of saccharin-treated (Sacc-Nic) WT mice by $61 \%$ over time course, compared with $23 \%$ in nicotine-treated (Nic-Nic) mice (treatment: $F_{1,330}=12.62, p=0.001$, treatment $\times$ time: $\left.\mathrm{F}_{11,330}=2.72, p=0.002\right)$. In contrast, nicotinetreated DAT KO mice did not show tolerance to the locomotor effect of the challenge dose of nicotine, which inhibited locomotor activity to the same extent whatever the pretreatment, that is $49 v s 65 \%$. Similar effects of the nicotine challenge were observed on vertical locomotor activity of treated- WT and -DAT KO mice (not shown). 

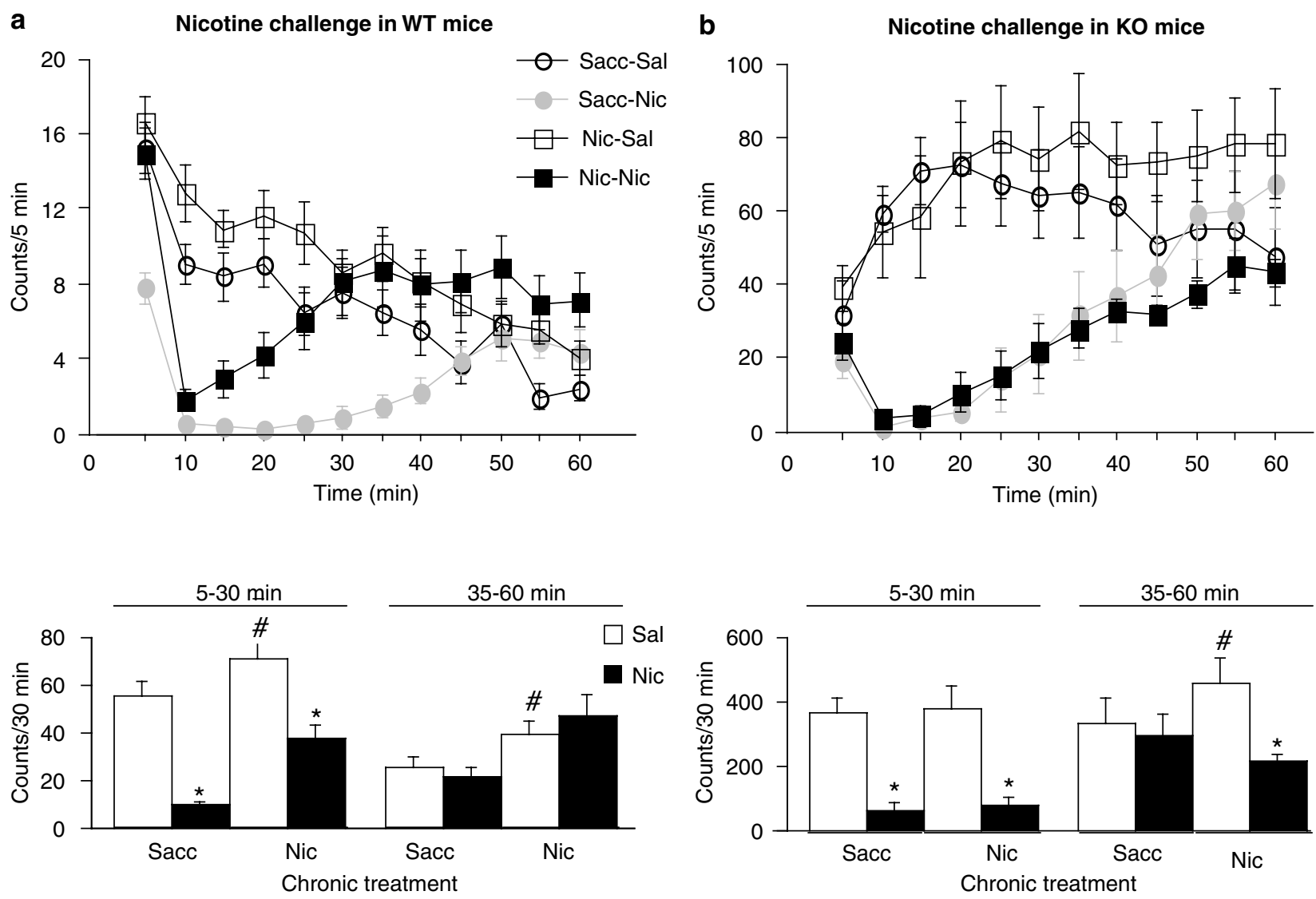

C Nicotine effect on nicotine-pretreated WT and DAT KO mice

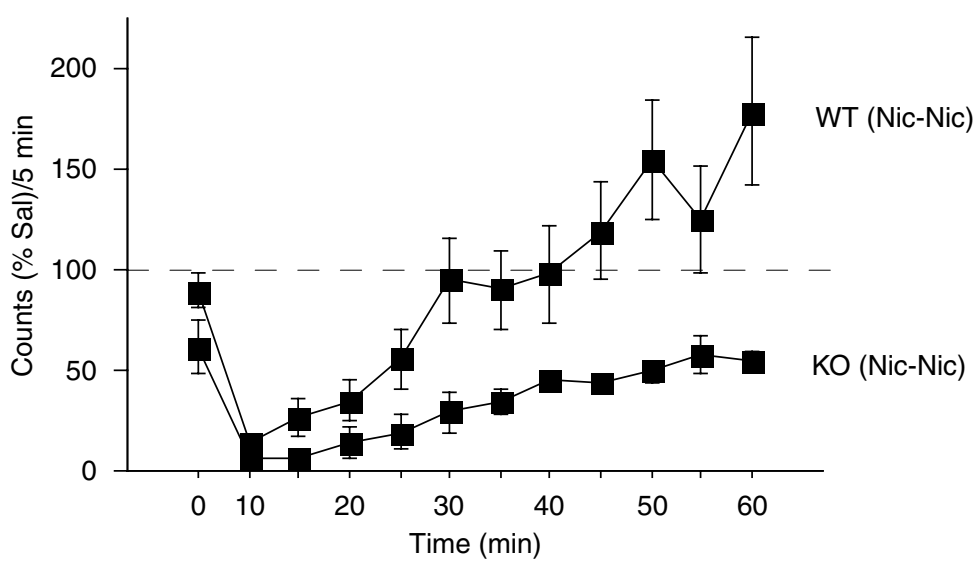

Figure 2 Locomotor effect of acute nicotine injection in chronic nicotine-treated WT and DAT KO mice after a $24 \mathrm{~h}$ withdrawal period. twenty-four hours after water was substituted to saccharin (Sacc) or nicotine (Nic), the effects of saline (Sal) or I mg/kg nicotine (Nic) were tested on the horizontal activity of WT (a) and DAT KO (b) mice. Means \pm SEM of photocell counts over a 5 min period during 60 min (top) and of cumulative counts over the first and last $30 \mathrm{~min}$ (bottom). In (c), nicotine-induced hypolocomotion (data from a and b, expressed as \% of respective saline values) was compared in nicotinetreated WT and DAT KO mice. Number of mice in parentheses, WT mice: Sacc-Sal (I7), Sacc-Nic (I5), Nic-Sal (20), Nic-Nic (I7); DAT KO mice: Sacc-Sal (8), Sacc-Nic (7), Nic-Sal (7), Nic-Nic (8). Fisher's test: ${ }^{\#}<0.05$, comparison between basal locomotor activity (saline treatment) of saccharin- or nicotinetreated mice; $* 0.00 \mathrm{I}$, comparison of nicotine effect between saccharin- and nicotine-treated mice of each genotype.

Finally, when compared with nicotine-treated WT mice, nicotine-treated DAT KO mice were still hypersensitive to nicotine-induced hypolocomotion (Figure 2c). The challenge nicotine treatment inhibited by $65 \%$ the locomotion of nicotine-treated DAT KO mice $v s 23 \%$ in nicotine-treated WT mice over the time course (genotype: $F_{1,253}=6.01$, $p=0.022$; genotype $\times$ time: $\left.\mathrm{F}_{11,253}=2.29, p=0.011\right)$.

\section{Chronic Nicotine Treatment did Not Elicit an Anxiogenic Effect in DAT KO Mice}

We previously showed that acute nicotine administration induced anxiety in WT mice, but not in DAT KO mice, when tested in the elevated plus maze apparatus (Weiss et al, 2007). We therefore assessed the effect of an 
Table I Effect of Chronic Nicotine Treatment on the Performance of WT and DAT KO Mice in the Elevated Plus Maze

\begin{tabular}{|c|c|c|c|c|c|}
\hline \multirow[b]{2}{*}{ Genotype } & \multirow[b]{2}{*}{ Treatment } & \multicolumn{2}{|c|}{ Time } & \multicolumn{2}{|c|}{ Number of entries } \\
\hline & & $O+C(s)$ & $\% \mathrm{O} / \mathrm{O}+\mathrm{C}$ & $O+C$ & $\mathrm{O} / \mathrm{O}+\mathrm{C}$ \\
\hline WT & Nic (10) & $223 \pm 10$ & $8.5 \pm 1.1 *$ & $17.9 \pm 1.9$ & $53.8 \pm 3.1$ \\
\hline
\end{tabular}
closed (C) arms of the elevated plus maze apparatus. The number of mice is indicated in parentheses.

Fisher's test: ${ }^{\$} p<0.05,{ }^{\$ \$} p<0.000$ I, comparison between genotype; ${ }^{*} p<0.01$, comparison with the saccharin group of the same genotype.

8-week nicotine treatment on the anxiety status of WT and DAT KO mice, by their performance on the elevated plus maze.

Both the time spent and the number of visits in the open arms were similar between males and females, irrespective of genotype (not shown). Accordingly, data for the two genders were pooled (Table 1). Statistical analyses showed no significant effect of genotype and treatment on the locomotor activity (total time spent and total number of entries in the open and closed arms), but a significant effect of genotype and treatment on the time spent in the open arms (genotype: $F_{1,33}=27.91, p<0.001$; genotype $\times$ treatment: $\left.\mathrm{F}_{1,33}=4.38, p=0.044\right)$. DAT KO mice spent significantly more time in the open arms than WT mice, regardless of their treatment, that is by $12 \%$ after saccharin treatment $\left(\mathrm{F}_{1,16}=8.56, p=0.010\right)$ and by $23 \%$ after nicotine treatment $\left(\mathrm{F}_{1,17}=20.09, p<0.001\right)$.

Interestingly, nicotine-treated WT mice spent twofold less time in the open arms than saccharin-treated WT mice $\left(\mathrm{F}_{1,18}=10.17, p=0.005\right)$. In contrast, chronic nicotine treatment had no effect on the performance of DAT KO mice, compared with saccharin treatment, in the elevated plus maze apparatus.

The Impaired Cued and Spatial Performance of DAT KO Mice were Improved by Nicotine, without Tolerance

We investigated the effects of both acute and chronic nicotine treatments on the performance of WT and DAT KO mice, in the cued or the spatial version of the Morris watermaze (Figures 3 and 4). In the two versions, the swimming speed of mice of both genotype did not vary significantly during trainings and did not differ between WT and DAT KO mice. Indeed, mean values over the entire training were $13.3 \pm 2.4$ vs $9.9 \pm 2.3 \mathrm{~cm} / \mathrm{s}$ in the cued training and $22.9 \pm 0.6 v s \quad 23.7 \pm 0.5 \mathrm{~cm} / \mathrm{s}$ in the spatial training, for WT and DAT KO mice, respectively (not shown).

To characterize the acute effect of nicotine, naive mice received saline or $0.35 \mathrm{mg} / \mathrm{kg}$ nicotine, $15 \mathrm{~min}$ before testing. To characterize the chronic and the chronic plus acute nicotine effects, saccharin-treated mice received saline, and nicotine-treated mice received saline or $0.35 \mathrm{mg} / \mathrm{kg}$ nicotine, $15 \mathrm{~min}$ before testing. Neither acute, nor chronic nicotine treatment had any effect on the swimming speed of WT and DAT KO mice (not shown).
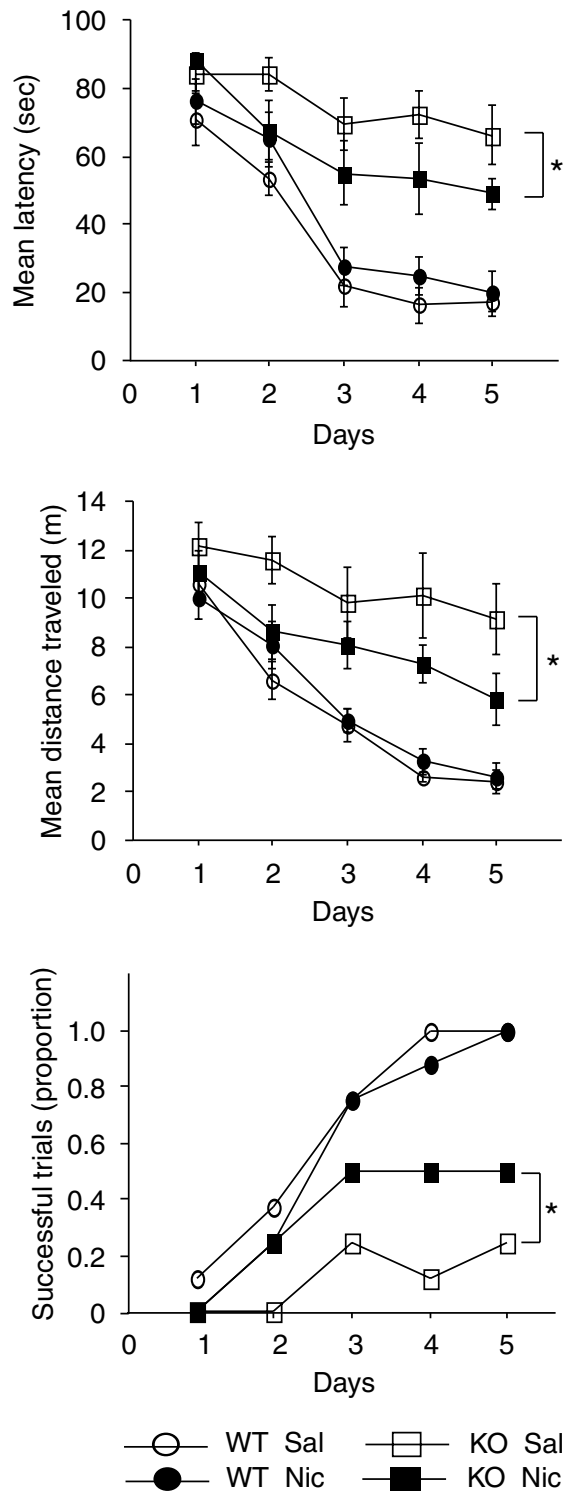

Figure 3 Effect of acute nicotine treatment on cued learning of WT and DAT $\mathrm{KO}$ mice in the Morris watermaze. $15 \mathrm{~min}$ before each training trial, the mice received saline (Sal) or $0.35 \mathrm{mg} / \mathrm{kg}$ nicotine (Nic). Their performance was expressed as latency (sec), distance traveled (m) and proportion of successful trials. Values are the means \pm SEM for eight mice per group. Fisher's test: $* 0<0.05$, comparison between saline and nicotine treatments. 
a

CUED LEARNING
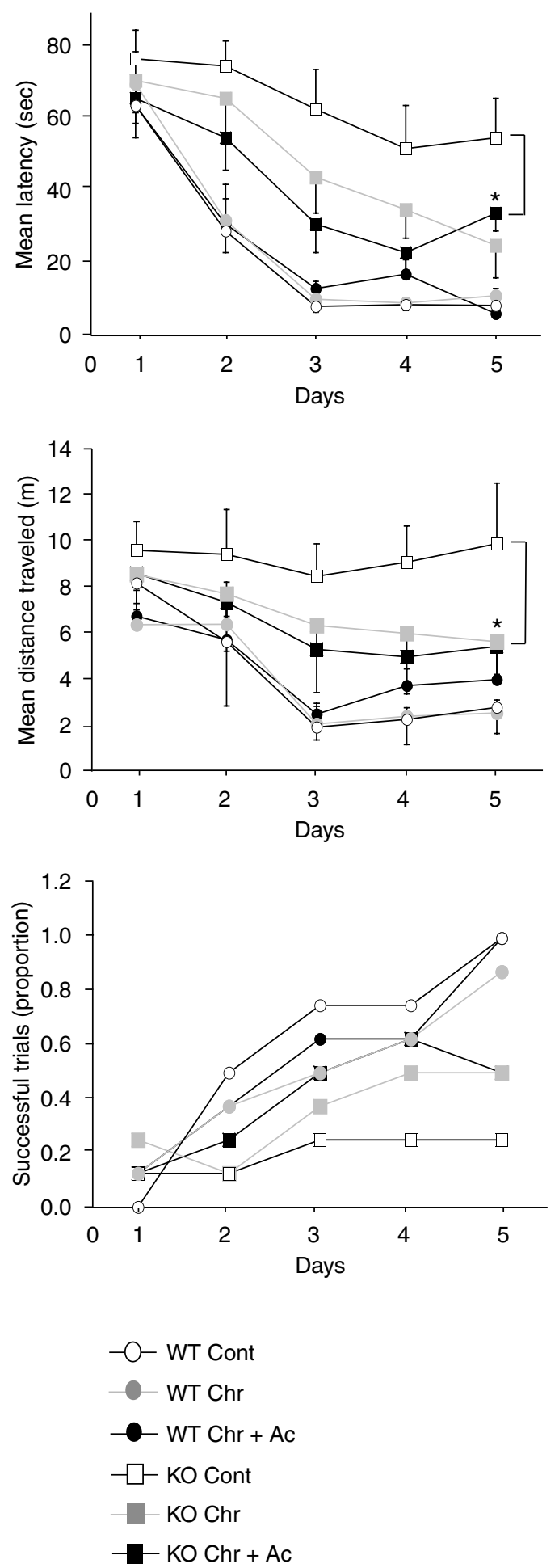

b SPATIAL LEARNING
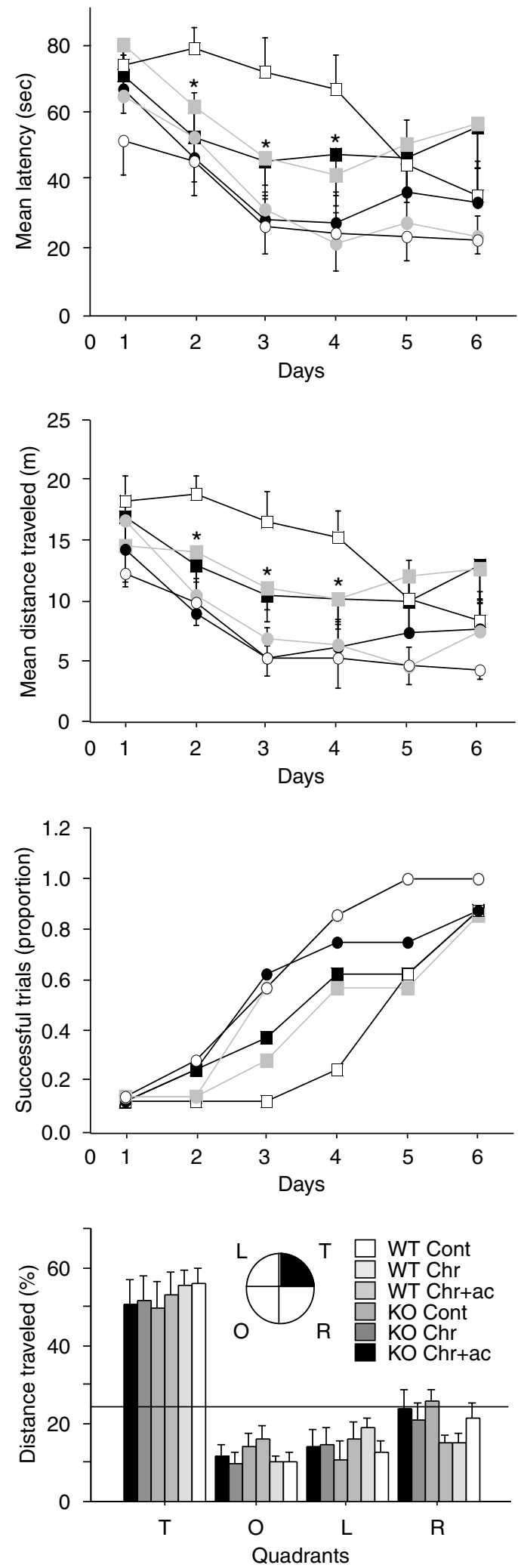

Figure 4 Effect of chronic or chronic plus acute nicotine treatment on cued and spatial learnings of WT and DAT KO mice in the Morris watermaze. After an 8-week saccharin or nicotine treatment, WT and DAT KO mice were tested for cued (a) and spatial (b) learning. Fifteen minutes before training trials, saccharin-treated mice received saline (Cont) and nicotine-treated mice received saline (Chr) or $0.35 \mathrm{mg} / \mathrm{kg}$ nicotine (Chr + Ac). Their performance was expressed as latency $(\mathrm{sec})$, distance traveled $(\mathrm{m})$ and proportion of successful trials. Values are the means \pm SEM for 7-8 mice per group. For quadrant trials carried out on day 7 (bottom), each histogram represented the mean distance (\% of total distance) traveled in each quadrant: target ( $\mathrm{T}$ ), opposite $(\mathrm{O})$, left $(L)$ and right $(R)$. Fisher's test: * $p<0.05$, comparison between saline and nicotine treatments. 
Acute effect of nicotine on cued learning. Analysis of the data from acute nicotine experiments (Figure 3) showed a significant effect of genotype and treatment on the latency (genotype: $\mathrm{F}_{1,112}=92.33, p<0.001$; genotype $\times$ treatment: $\mathrm{F}_{1,112}=9.83, p=0.004$; genotype $\times$ training: $\mathrm{F}_{4,112}=4.32$, $p=0.003$ ) and on the distance traveled (genotype: $\mathrm{F}_{1,112}=47.82, p<0.001$; genotype $\times$ treatment: $\mathrm{F}_{1,112}=6.43$, $p=0.017$; genotype $\times$ training: $\mathrm{F}_{4,112}=4.19, p=0.003$ ).

DAT KO mice exhibited impaired performance when compared to their WT littermates. During the 5-day training, their mean latency was significantly longer than that of WT mice by $108 \%$ (genotype: $F_{1,56}=65.76, p<0.001$; genotype $\times$ training: $\mathrm{F}_{4,56}=4.32, p=0.004$; Figure 3$)$, the distance to reach the platform was higher by $96 \%$ (genotype: $\mathrm{F}_{1,56}=41.76, \quad p<0.001 ; \quad$ genotype $\times$ training: $\left.\mathrm{F}_{4,56}=2.81, p=0.034\right)$ and the proportion of their successful trials was significantly lower $\left(\chi^{2}=7.20, p=0.003\right)$.

Acute treatment by nicotine had no significant effect on the performance of WT mice in cued learning. In contrast, acute nicotine treatment improved the performance of DAT KO mice on days $1-5$. Acute $0.35 \mathrm{mg} / \mathrm{kg}$ nicotine administration significantly decreased the mean latency of DAT KO mice by $17 \%$ (treatment: $F_{1,56}=5.89, p=0.029$ ), significantly decreased their mean distance traveled to reach the platform by $22 \%$ (treatment: $\mathrm{F}_{1,56}=5.64, p=0.032$ ) and significantly increased their successful trials $\left(\chi^{2}=3.20, p=0.038\right)$.

Chronic effects of nicotine on cued learning. Analysis of chronic and chronic + acute nicotine experiments (Figure 4a) showed a significant effect of genotype and treatment on the latency time (genotype: $\mathrm{F}_{1,168}=51.11$, $p<0.001$; genotype $\times$ treatment: $\left.\mathrm{F}_{1,168}=4.44, p=0.018\right)$ and on the distance traveled (genotype: $\mathrm{F}_{1,168}=31.96, p<0.001$; genotype $\times$ treatment: $\left.\mathrm{F}_{1,112}=4.83, p=0.013\right)$.

Neither chronic, nor chronic + acute treatment by nicotine had a significant effect on the performance of WT mice in cued learning. In contrast, chronic oral nicotine treatment improved, although not significantly, the performance of DAT KO mice, compared with saccharin-treated mice (Figure 4a). During the 5-day training, it decreased their latency by $26 \%$ (treatment: $F_{1,56}=3.26, p=0.092$ ) and their mean distance traveled by $27 \%$ (treatment: $F_{1,56}=4.53$, $p=0.052)$ and enhanced the number of successful trials $\left(\chi^{2}=3.20, p=0.038\right)$. Finally, when nicotine-treated DAT KO mice received acute $0.35 \mathrm{mg} / \mathrm{kg}$ nicotine $15 \mathrm{~min}$ before the test, their performance was significantly improved, compared with saccharin-treated DAT KO mice. Their latency and mean distance traveled were significantly decreased by 35 and $34 \%$ during the 5-day training (treatment: $F_{1,56}=6.57$, $p=0.023$ and $F_{1,56}=6.29, p=0.025$, respectively) and the proportion of successful trials was increased between days 2 and $4\left(\chi^{2}=2.80, p=0.040\right)$.

Chronic effects of nicotine on spatial learning. Analysis of chronic and chronic + acute nicotine experiments (Figure $4 \mathrm{~b}$ ) showed a significant effect of genotype between days 1 and 6 on the latency (genotype: $F_{1,250}=25.93$, $p<0.001$; genotype $\times$ treatment: $\left.\mathrm{F}_{1,250}=3.19, p=0.031\right)$ and on the distance traveled (genotype: $\mathrm{F}_{1,250}=23.69, p<0.001$; genotype $\times$ treatment: $\left.F_{1,250}=2.76, p=0.050\right)$.

DAT KO mice exhibited a delayed acquisition of spatial learning, when compared with WT mice (compared KO
Control with WT Control). The latency time of DAT KO mice was significantly increased by $93 \%$ over 6 -day training (genotype: $F_{1,65}=19.93, p=0.001$ ) and the distance they covered was significantly higher by $109 \%$ (genotype: $\mathrm{F}_{1,65}=17.90, p=0.001$ ). Finally, the proportion of successful trials was significantly less for DAT KO mice, compared to that of WT mice during the 6-day training $\left(\chi^{2}=7.47\right.$, $p=0.003)$. At the end of the 6-day training, WT and DAT KO mice exhibited the same level of performance, indicating that spatial learning had occurred.

Chronic and chronic + acute nicotine administrations had no significant effect on the performance of WT mice (Figure $4 \mathrm{~b}$ ). In contrast, both nicotine treatments improved the performance of DAT KO mice. Chronic nicotine treatment significantly decreased the latency of DAT KO mice by $9 \%$ for 6 -day training (treatment $\times$ training: $\left.\mathrm{F}_{5,65}=2.73, p=0.027\right)$ and by $31 \%$ between days 2 and 4 (treatment: $\mathrm{F}_{1,26}=5.17, p=0.040$ ), tend to decrease the traveled distance by $30 \%$ between days 2 and 4 (treatment: $\left.\mathrm{F}_{1,26}=4.42, p=0.056\right)$ and greatly increased the number of successful assays of mutant mice between days 2 and 4 $\left(\chi^{2}=2.80, p=0.040\right)$. Moreover, chronic oral nicotine treatment followed by acute $0.35 \mathrm{mg} / \mathrm{kg}$ nicotine improved more significantly performance of DAT KO mice, by decreasing the time and the distance traveled by $33 \%$ between days 2 and 4 (treatment: $\mathrm{F}_{1,28}=5.14, p=0.039$, and $\mathrm{F}_{1,28}=5.77, p=0.031$, respectively) and increasing the number of successful trials $\left(\chi^{2}=2.80, p=0.040\right)$.

Finally, the probe trial, performed at the end of the training session (Figure $4 \mathrm{~b}$ ), indicated that mice traveled more distance in the target $(\mathrm{T})$ quadrant regardless of genotype and treatment, suggesting the use of a spatial strategy when locating the hidden platform.

\section{Differential Effects of Nicotine Treatment on the Density of Dopaminergic and Nicotinic Receptors in the Brain of WT and DAT KO Mice}

We examined the effect of chronic nicotine treatment on the relative density of DAergic and nicotinic receptors in regions where DAergic and nicotinic neurotransmission are colocalized. In all areas tested in this study, $\left[{ }^{125} \mathrm{I}\right]$-epibatidine at low concentrations is a specific ligand of $\beta 2$ subunits (Marks et al, 2006). Autoradiographic labeling with this ligand is entirely suppressed in mice lacking the $\beta 2$ subunit gene (Zoli et al, 1998) and recovered by its re-expression in the ventral tegmental area (Maskos et al, 2005).

Effects of chronic saccharin treatment on DAergic and nicotinic receptor density. Saccharin-treated DAT KO mice, compared with saccharin-treated WT mice, exhibited high modifications of DAergic (Table 2) and nicotinic receptor density (Table 3), to the same extent and in the same areas than reported previously under basal conditions (Weiss et al, 2007). Briefly, the relative density of the D1 DAergic receptors was decreased by $22-68 \%$ in all tested areas of DAT KO mice, except in the cingulate cortex (genotype $\times$ area: $\mathrm{F}_{4,46}=24.29, p<0.001$ ). The density of the D2 DAergic receptor was decreased by $33-63 \%$ in all areas tested (genotype $\times$ area: $F_{5,49}=6.06$, $p<0.001$ ) and the density of the D3 receptor increased by $31-77 \%$ in all areas tested, except in the shell and core parts 
Table 2 Effect of Chronic Nicotine Treatment on the DAergic Receptor Density in Various Brain Areas of WT and DAT KO Mice

\begin{tabular}{|c|c|c|c|c|c|c|c|}
\hline \multirow[b]{2}{*}{ Receptor } & \multirow[b]{2}{*}{ Area } & \multicolumn{3}{|c|}{ WT } & \multicolumn{3}{|c|}{ ко } \\
\hline & & Sacc- & Nic- & $\%$ Nic/Sacc & Sacc- & Nic- & $\%$ Nic/Sacc \\
\hline & Striatum & (6) $143 \pm 7$ & (5) $126 \pm 4$ & $-12 \mathrm{NS}$ & (6) $66 \pm 2^{\ddagger \ddagger}$ & (6) $7 \mid \pm 3$ & $+7 \mathrm{NS}$ \\
\hline & Acc Shell & (6) $82 \pm 9$ & (6) $83 \pm 6$ & $+I N S$ & (5) $29 \pm I^{\ddagger \ddagger \ddagger}$ & (5) $36 \pm 2$ & $+23^{*}$ \\
\hline \multirow[t]{4}{*}{ D2 } & SNC & (6) $|49 \pm 1|$ & (6) $|4| \pm 5$ & $-6 \mathrm{NS}$ & (4) $55 \pm 5^{\ddagger \ddagger \ddagger}$ & (6) $48 \pm 2$ & -14 NS \\
\hline & SNR & (6) $42 \pm 3$ & (6) $40 \pm 3$ & -6 NS & (5) $28 \pm 3^{\ddagger}$ & (6) $21 \pm 1$ & $-24 *$ \\
\hline & VTA & (5) $120 \pm 10$ & (6) $114 \pm 7$ & $-5 \mathrm{NS}$ & (5) $50 \pm 5^{\ddagger \ddagger}$ & (6) $46 \pm 2$ & $-8 \mathrm{NS}$ \\
\hline & Striatum & (5) $318 \pm 22$ & (5) $270 \pm 3$ & $-15 \mathrm{NS}$ & (5) $202 \pm 10^{\ddagger \ddagger}$ & (5) $177 \pm 20$ & $-12 \mathrm{NS}$ \\
\hline \multirow[t]{6}{*}{ D3 } & SNC & (6) $76 \pm 3$ & (5) $82 \pm 8$ & $+8 \mathrm{NS}$ & (6) $110 \pm 9^{\ddagger \ddagger}$ & (6) $115 \pm 5$ & $+4 \mathrm{NS}$ \\
\hline & SNR & (5) $30 \pm 2$ & (5) $32 \pm 5$ & $+6 \mathrm{NS}$ & (6) $53 \pm 5^{\ddagger \ddagger}$ & (6) $57 \pm 6$ & $+7 \mathrm{NS}$ \\
\hline & VTA & (6) $15 \pm 1$ & (5) $21 \pm 1$ & $+33^{*} * *$ & (6) $22 \pm 1^{\ddagger \ddagger}$ & (6) $25 \pm 2$ & $+11 \mathrm{NS}$ \\
\hline & Str DL & (5) $16 \pm 1$ & (6) $18 \pm 1$ & $+10 \mathrm{NS}$ & (5) $21 \pm 1^{\ddagger}$ & (6) $18 \pm 1$ & $-17 \mathrm{NS}$ \\
\hline & Acc Shell & (6) $170 \pm 4$ & (5) $200 \pm 4$ & +18 ****** & (6) $165 \pm 4$ & (6) $176 \pm 8$ & $+7 \mathrm{NS}$ \\
\hline & Acc Core & (6) $114 \pm 9$ & (5) $106 \pm 13$ & $-7 \mathrm{NS}$ & (6) $110 \pm 9$ & (6) $109 \pm 7$ & 0 \\
\hline
\end{tabular}

Acc, nucleus accumbens; cing Cx, prelimbic cingulate cortex; SNC, substantia nigra pars compacta; SNR, substantia nigra pars reticulata; Str DL, dorso-lateral striatum; VTA, ventral tegmental area.

Densities, in means \pm SEM of specific radioligand binding in arbitrary units, are determined after chronic saccharin (Sacc) and nicotine (Nic) treatment. The number of mice is indicated in parentheses.

Fisher's test: ${ }^{\ddagger} p<0.05,{ }^{\ddagger \ddagger} p<0.01,{ }^{\ddagger \ddagger} p<0.001$, comparison between genotype; ${ }^{*} p<0.05$, $* * * 0.01, * * * * 0.00$ I, comparison with respective values in saccharintreated mice.

of the nucleus accumbens (genotype $\times$ area: $\mathrm{F}_{5,56}=5.01$, $p<0.001)$.

The relative density of $\beta 2^{*} \mathrm{nAChR}$ in DAT KO mice was significantly decreased by $15-20 \%$ in all areas tested, except in the substantia nigra pars compacta and the prelimbic cortex (genotype: $\mathrm{F}_{1,60}=29.04, p<0.001$ ). The relative density of the $\alpha 6^{*}$ subunit was significantly decreased by $25-35 \%$ in all areas tested, except in the ventral tegmental area and the nucleus accumbens (genotype $x$ area: $\left.\mathrm{F}_{5,47}=5.17, p<0.001\right) . \alpha 7$ receptor density was significantly increased by $15-40 \%$ in the substantia nigra, the ventral tegmental area, the dorso-lateral striatum and the shell and the core parts of the nucleus accumbens, it was significantly decreased by $17 \%$ in the prelimbic cortex and was not modified in the amygdala and hippocampus (genotype $\times$ area: $\left.\mathrm{F}_{7,73}=4.88, p=0.001\right)$.

Effects of chronic nicotine treatment on dopaminergic receptor density. The effects of chronic nicotine treatment on the relative density of DAergic receptors were genotype-, area- and subtype-dependent (Table 2). The treatment significantly decreased by $20 \%$ the density of D1 receptors in the pars reticulata of the substantia nigra of WT mice $\left(\mathrm{F}_{1,9}=6.91, p=0.027\right)$, but had no effect in other areas as reported previously in mice after such treatment (Pietila et al, 1996). It had no effect on the density of $\mathrm{D} 2$ receptors in WT mice, but significantly increased the density of D3 receptors by $33 \%$ in the ventral tegmental area $\left(\mathrm{F}_{1,9}=10.65\right.$, $p=0.003)$ and by $18 \%$ in the shell part of the nucleus accumbens of WT mice $\left(\mathrm{F}_{1,9}=23.16, p<0.001\right)$.

In DAT KO mice, nicotine treatment significantly increased the density of D1 receptors by $23 \%$ in the shell part $\left(\mathrm{F}_{1,8}=6.55, p=0.034\right)$ and by $38 \%$ in the core part $\left(\mathrm{F}_{1,10}=5.38, p=0.043\right)$ of the nucleus accumbens; it significantly decreased by $24 \%$ the density of $\mathrm{D} 2$ receptors in the substantia nigra pars reticulata $\left(\mathrm{F}_{1,9}=5.08, p=0.050\right)$ and had no effect on the density of D3 receptors in any area tested.

Effects of chronic nicotine treatment on nicotinic receptor density. The effects of chronic nicotine treatment on the relative density of nAChRs were also genotype-, area- and subtype-dependent (Table 3 ). In WT mice, nicotine treatment significantly increased the density of $\beta 2^{*}$ subunits by $10 \%$ in the striatum $\left(\mathrm{F}_{1,10}=9.49, p=0.012\right)$ and the prelimbic cortex $\left(\mathrm{F}_{1,10}=5.76, p=0.037\right)$. It significantly decreased the density of $\alpha 6^{*}$ subunits by $27 \%$ in the substantia nigra pars compacta $\left(\mathrm{F}_{1,9}=45.04, p<0.001\right)$, by $25 \%$ in the substantia nigra pars reticulata $\left(\mathrm{F}_{1,10}=14.91, p=0.003\right)$, by $19 \%$ in the striatum $\left(\mathrm{F}_{1,10}=42.08, p<0.001\right)$ and by $13 \%$ in the nucleus accumbens $\left(\mathrm{F}_{1,8}=12.18, p=0.008\right)$. Finally, it significantly decreased the density of $\alpha 7$ receptors by $15 \%$ in the substantia nigra $\left(\mathrm{F}_{1,10}=43.88, p<0.001\right)$ and by $10 \%$ in the hippocampus $\left(\mathrm{F}_{1,10}=5.47, p=0.042\right)$. 
Table 3 Effect of Chronic Nicotine Treatment on the Nicotinic Receptor Density in Various Brain Areas of WT and DAT KO Mice

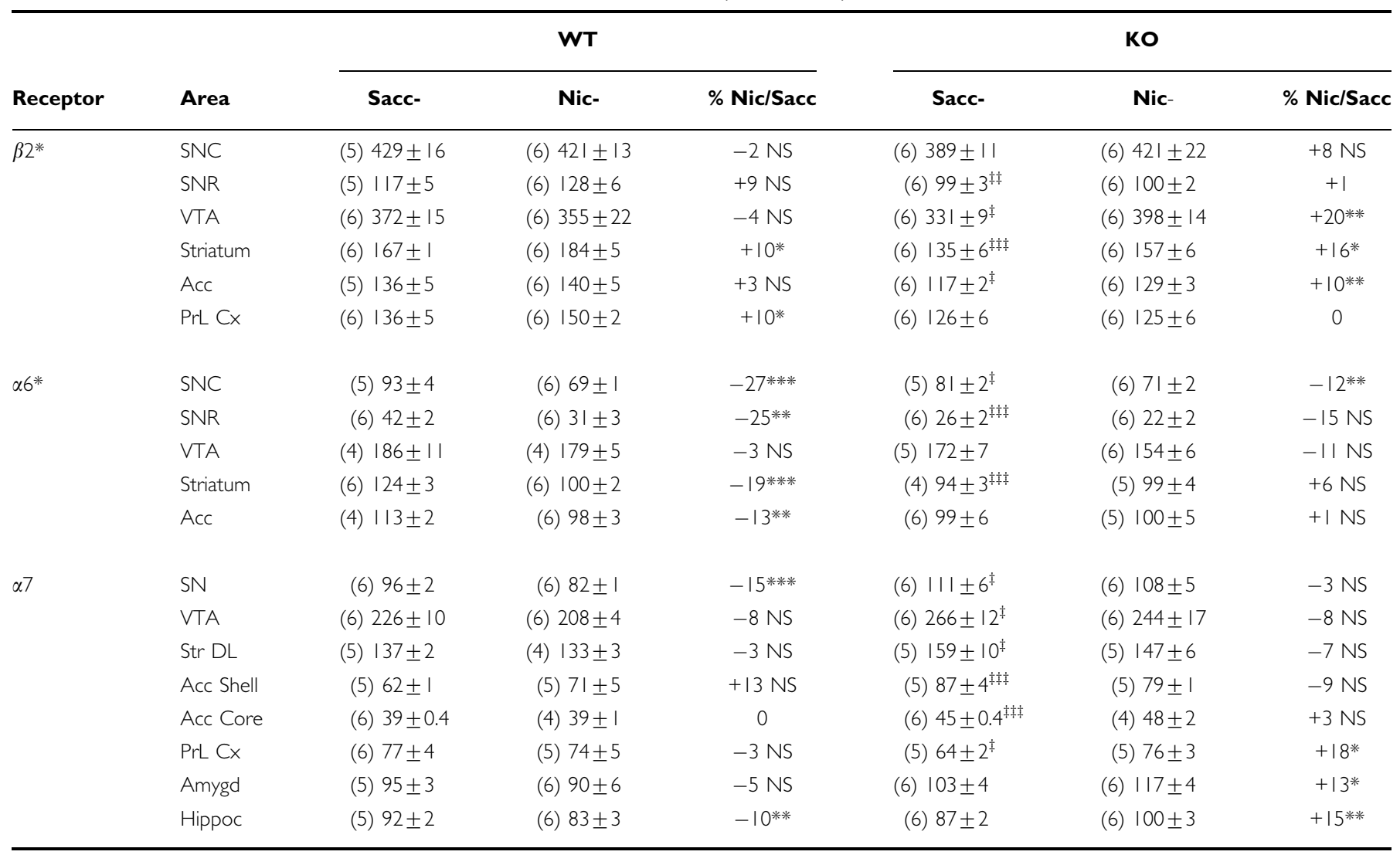

Acc, nucleus accumbens; Amygd, amygdala; Hippoc, hippocampus; PrL Cx, prelimbic cortex; SN, substantia nigra, pars compacta+reticulata; SNC, substantia nigra pars compacta; SNR, substantia nigra pars reticulata; Str DL, dorso-lateral striatum; VTA, ventral tegmental area.

Densities, in means \pm SEM of specific binding in arbitrary units, are determined after chronic saccharin (Sacc) and nicotine (Nic) treatments. The number of mice is indicated in parentheses.

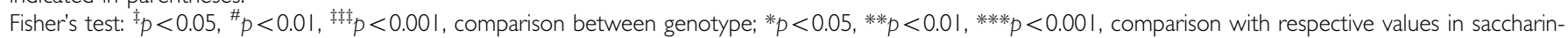
treated mice.

In DAT KO mice, chronic nicotine treatment increased the density of $\beta 2^{\star}$ subunits by $20 \%$ in the ventral tegmental area $\left(\mathrm{F}_{1,10}=16.80, p=0.002\right)$, by $16 \%$ in the striatum $\left(\mathrm{F}_{1,10}=7.43, p=0.021\right)$ and by $10 \%$ in the nucleus accumbens $\left(\mathrm{F}_{1,10}=10.52, p=0.009\right)$. It decreased the density of $\alpha 6^{*}$ subunits by $12 \%$ in the pars compacta of the substantia nigra $\left(\mathrm{F}_{1,9}=11.71, p=0.008\right)$. Interestingly, nicotine treatment increased by $18 \%$ the density of $\alpha 7$ receptors in the prelimbic cortex $\left(\mathrm{F}_{1,8}=10.62, p=0.012\right)$, so that $\alpha 7$ receptor density in this area of nicotine-treated DAT KO mice no longer differed from that of saccharin-treated WT mice. It also significantly increased the $\alpha 7$ receptor density by $13 \%$ in the amygdala $\left(\mathrm{F}_{1,10}=5.05, p=0.048\right)$ and by $15 \%$ in the hippocampus $\left(\mathrm{F}_{1,10}=13.66, p=0.004\right)$.

\section{DISCUSSION}

Our data demonstrated that oral chronic nicotine treatment induced biochemical and behavioral adaptations that depend on the DAergic neurotransmission tone. Constitutively hyperDAergic DAT KO mice were persistently hypersensitive, and not tolerant, to nicotine-induced hypolocomotion and they were not affected by the anxiogenic effect of nicotine treatment observed in WT mice. Very interestingly, their impaired performance in cued learning was greatly improved by acute nicotine treatment. More importantly, DAT KO mice were not tolerant to the procognitive effect of nicotine, because of its effect on performance in both cued and spatial learnings persisted even after an 8-week treatment. The procognitive effect of nicotine in DAT KO mice paralleled the normalization or the increase in $\alpha 7 \mathrm{nAChR}$ density in the hippocampus, the amygdala, and the prelimbic cortex, all areas involved in learning.

\section{Modulation of DAergic and Nicotinic Receptor Densities by Chronic Nicotine Treatment Depended on the DAergic Neurotransmission Tone}

Altogether, our results suggest that oral chronic nicotine treatment modulated the density of DAergic and nicotinic receptors in a manner dependent on the strength of DAergic neurotransmission. Variations were opposite in the case of the D1 DAergic receptor density, which decreased in WT mice, but increased in hyperDAergic DAT KO mice. Chronic nicotine had no effect on the density of D2 receptors in WT mice, as reported previously in mice (Pietila et al, 1996), but decreased D2 receptor density in DAT KO mice. It increased the density of D3 receptors in 
WT mice, as already reported in rats (Le Foll et al, 2003), but had no effect on D3 density in DAT KO mice.

In both $\mathrm{WT}$ and DAT KO mice, oral chronic nicotine treatment increased $\beta 2^{*} \mathrm{nAChRs}$ in line with previous results in control mice (for reviews, see Buisson and Bertrand, 2002; Gentry and Lukas, 2002) and decreased $\alpha 6^{*}$ nAChRs, as reported previously with autoradiographic labelings in control mouse or rat brain (Lai et al, 2005; Mugnaini et al, 2006), but in contrast with other data from labelings on particulate fractions of rat cerebral areas (Parker et al, 2004). Finally, such a treatment induced opposite variations of $\alpha 7 \mathrm{nAChRs}$, which decreased in WT and increased in DAT KO mice. The decreased $\alpha 7 \mathrm{nAChR}$ density induced by chronic nicotine treatment of WT mice contrasted with previous results showing upregulation (Sparks and Pauly, 1999; Nuutinen et al, 2005; Pakkanen et al, 2005). However, in our study the administered dose of nicotine was much lower compared with other studies in mice $(70 \mu \mathrm{g} / \mathrm{ml} v s$ increasing doses from 50 to $500 \mu \mathrm{g} / \mathrm{ml}$ at the end of treatment). Very interestingly, the nicotine treatment of DAT KO mice normalized the decreased basal $\alpha 7 \mathrm{nAChR}$ density in the prelimbic cortex and upregulated the density in the hippocampus and amygdala, all areas related to the procognitive effect of nicotine (see below).

Finally, potential circuitry/developmental adaptations could impact the nicotinic neurotransmission alterations we observed in DAT KO mice. This hypothesis is suggested by the colocalization of DAT, D2, and D3 autoreceptors and some $\mathrm{nAChRs}$ as $\alpha 4 \beta 2$ receptors on midbrain neurons (Diaz et al, 2000; for reviews, see Wonnacott, 1997; Le Novere et al, 2002) and studies reporting a role of D2 DAergic receptors and $\alpha 4^{\star} \mathrm{nAChR}$ subunits in modulating the neuronal arbor (Parish et al, 2005).

\section{Nicotine-Treated DAT KO Mice were Not Tolerant to the Nicotine-Induced Hypolocomotion}

Chronic nicotine treatment had no calming effect on the basal constitutive hyperactivity of DAT KO mice. However, we have used a rather low dose of nicotine and we recorded the mouse locomotion between $1000 \mathrm{~h}$ and $1400 \mathrm{~h}$, but not during the dark cycle which represents their active phase.

After 8 weeks of nicotine treatment in the drinking water and $24 \mathrm{~h}$ withdrawal, WT mice exhibited tolerance to the hypolocomotion induced by a challenge dose of nicotine, as reported previously (Sparks and Pauly, 1999; Pietila and Ahtee, 2000; for reviews, see Malin, 2001; Picciotto and Corrigall, 2002). In contrast, such chronic treatment did not induce tolerance of DAT KO mice to nicotine-induced hypolocomotion.

Discontinuous nicotine treatment has been reported previously to elicit upregulation of nAChRs, potentially by post-transcriptional mechanisms and to promote a decrease in $\mathrm{nAChR}$ functional responsiveness (for reviews, see Buisson and Bertrand, 2002; Gentry and Lukas, 2002). In our study, tolerance of WT mice to nicotine-induced hypolocomotion could be owing to decreased (or desensitized) levels of nAChRs and/or DAergic receptors involved in hypolocomotion. Alternatively, it can also be owing to increased (or sensitized) levels of receptors involved in hyperactivity. As DAT KO mice did not exhibit tolerance, such modulations are most probably not present in these mice. Among nAChR subtypes, $\alpha 7$ receptors are good candidates to explain nicotine responsiveness of WT and DAT KO mice, because their density was decreased by chronic nicotine treatment in WT mice, but increased in DAT KO mice. Moreover, their stimulation has been previously implicated in nicotine-induced hypolocomotion in our mouse lines (Weiss et al, 2007). Still, we have not characterized the sensitization state of nAChRs in WT and DAT KO mice, so that involvement of $\beta 2^{\star}$ and $\alpha 6^{*}$ subtypes cannot be ruled out. Among DAergic receptors, D3 receptors are good candidates, as D3 KO mice displayed hyperlocomotion (Accili et al, 1996) and because nicotine treatment elicited increased density in WT mice, but no effect in DAT KO mice. In addition, taking into account the colocalization of D1 and D3 receptors in accumbal neurons and their opposite or synergistic influence (for a review, see Schwartz et al, 1998), we can postulate that an imbalance between the levels of D1 and D3 receptors could be responsible for the differential locomotor effects of chronic nicotine in WT (decreased D1/D3) and DAT KO mice (increased D1/D3).

Whatever the mechanism involved in tolerance of WT mice, our data showed that the calming effect of nicotine on the hyperactivity of DAT KO mice could persist even after an 8-week chronic treatment.

\section{Chronic Nicotine Treatment did Not Elicit an Anxiogenic Effect in DAT KO Mice}

There is strong evidence that serotonin tone plays a permissive role in nicotine modulation of anxiety (for a review, see Seth et al, 2002). Previous studies show that some opposite behaviors of WT and DAT KO mice can be attributed to imbalance between DA and serotonin neurotransmissions (Gainetdinov et al, 1999b; Spielewoy et al, 2001; Barr et al, 2004). It was thus interesting to test the anxiety status of WT and DAT KO mice after chronic nicotine treatment. We showed that DAT KO mice spent more time in the open arms than their WT counterparts, suggesting that they were less anxious in the elevated plus maze apparatus. The decreased anxiety of DAT KO mice, which should be confirmed by other paradigms, was not related to their hyperactivity, because both genotypes had the same number of entries.

As did an acute treatment (Weiss et al, 2007), chronic nicotine treatment induced an anxiogenic effect on WT mice, indicating that these mice were not tolerant to the anxiogenic effect of nicotine. Interestingly, neither acute (Weiss et al, 2007), nor chronic nicotine treatment elicited anxiety in DAT KO mice. These data supported the existence of a different balance of $\mathrm{DA} /$ serotonin neurotransmissions between WT and DAT KO mice.

Nicotine Treatment Improved the Performance of DAT KO Mice in Cued and Spatial Learning, without Eliciting Tolerance

Cognitive impairments, mainly affecting working memory, attention, and response inhibition, are considered as a core feature of schizophrenia (for a review, see Green, 2006) and ADHD (for a review, see Barkley, 2003). Nicotine has proven to be effective to improve some of the cognitive 
deficits in schizophrenia and ADHD (for reviews, see Levin, 2002; Levin and Rezvani, 2002; Sacco et al, 2004). Previous studies in our lab have shown that DAT KO mice exhibited impaired performance in the Morris watermaze paradigms (Morice et al, 2007) involving memory, attentional processes, and cognitive flexibility (for a review, see D'Hooge and De Deyn, 2001). Consequently, we chose to test the effect of acute and chronic nicotine administration on the performance of mice in the cued and spatial versions of the Morris watermaze.

Surprisingly, DAT KO mice did not exhibit a significantly higher swimming speed than WT mice in both versions of the Morris watermaze. The absence of hyperactivity of mutant mice was also seen in the elevated plus maze test. This could be because of more stressful conditions of the watermaze and the plus maze tests, compared to actimetry.

DAT KO mice exhibited impaired or delayed performance in the cued and the spatial versions of the Morris watermaze test, respectively, in agreement with previous observations (Morice et al, 2007). The poor cognitive performance of mutant mice could not be owing to their anxiety status, because they exhibited better performance than WT mice in the elevated plus maze test. Very interestingly, we showed that the cognitive deficits of DAT KO mice in the cued learning were improved by both acute and chronic nicotine treatments, without tolerance even after an 8-week treatment. We also showed that the deficits of DAT KO mice in the spatial learning were improved by a chronic nicotine treatment.

Numerous studies in humans and rodents demonstrate the pro-cognitive effect of nicotine treatment (for reviews, see Buccafusco et al, 2005; Levin et al, 2006). Data from the literature indicate that the working memory performance of rodents is improved by the stimulation, or the co-stimulation, of nAChRs in the hippocampus, the dorsal striatum and the baso-lateral amygdala (Levin et al, 2002; for reviews, see Packard and Knowlton, 2002; Levin et al, 2006). In addition, the attention-enhancing effect of nicotine is mediated by the prefrontal cortical nicotinic receptors (for a review, see Mansvelder et al, 2006). Interestingly, DAT KO mice had a lower $\alpha 7$ receptor density in their prelimbic cortex than WT mice, perhaps in relation to their impaired cognitive performance. In contrast, there was no variation of the basal $\alpha 7$ receptor density in the hippocampus of DAT KO mice compared to WT mice. One explanation for the impaired performance of mutant mice in the spatial version is that the $\alpha 7$ receptors in hippocampus, known to be involved in spatial learning, may be understimulated by basal ACh release. Interestingly, chronic nicotine treatment induced a significant $15-20 \%$ increase of $\alpha 7 \mathrm{nAChR}$ density in the prelimbic cortex, the amygdala, and the hippocampus of DAT KO mice. These results suggest the involvement of functional $\alpha 7$ nAChRs in the pro-cognitive effect of chronic nicotine treatment in DAT KO mice. Such a hypothesis is in agreement with previous studies showing impaired performance of $\alpha 7$ nAChR knockout mice (Young et al, 2004, 2007; Keller et al, 2005). Deficit in sensory gating in schizophrenic patients has been suggested to be linked to $\alpha 7 \mathrm{nAChR}$ (for a review, see Adler et al, 1998) and can be improved by DMXB$\mathrm{A}$, an $\alpha 7 \mathrm{nAChR}$ agonist (Olincy et al, 2006). In addition, cognitive deficits associated with Alzheimer's disease are also improved by DMXB-A (for a review, see Kem, 2000). Finally, a recent study in our laboratory has also shown that the impaired performance of DAT KO mice in the cued version of the watermaze was improved by acute DMXB-A (El Khouzy et al, in preparation), reinforcing the idea that the beneficial effects of nicotine on the cognitive functions of DAT KO mice may be mediated by $\alpha 7 \mathrm{nAChR}$ stimulation.

Acute nicotine treatment did not elicit pro-cognitive effects in WT mice. This lack of improvement is in agreement with previous reports on mouse performance in watermaze (Bernal et al, 1999; Vicens et al, 2003; Moragrega et al, 2003). More surprisingly, chronic nicotine treatments did not improve the performance of WT mice, in contrast with numerous studies (Bernal et al, 1999; for reviews, see Buccafusco et al, 2005; Levin et al, 2006). This suggests that WT mice were less sensitive than DAT KO mice to the pro-cognitive effect of nicotine. Alternatively, nicotine could exert pro-cognitive effects only when learning is impaired, depending for example on genetic background (van Dam et al, 2006). This hypothesis is also suggested by studies on healthy and diseased humans (for a review, see Sacco et al, 2004). This feature reinforces the validity of our animal model towards psychiatric diseases.

In conclusion, our data demonstrated that DAT KO mice, which represent a pertinent model for various symptoms encountered in schizophrenia and ADHD, were not tolerant to the 'calming' locomotor effect of oral chronic nicotine treatment. Moreover, acute and chronic nicotine alleviated cognitive deficits, without the side effects of tolerance and anxiogenesis. These beneficial effects could be associated with a normalization or an increase of cholinergic neurotransmission. Data from our previous and present studies suggest that DAT KO mice can be used to identify the molecular effects of nicotine and to understand the nicotine self-medication of psychiatric patients. In addition, they suggest that a combination of nicotinic receptor agonists might favorably lead to additional therapy of some psychiatric diseases.

\section{ACKNOWLEDGEMENTS}

We thank Drs S Gautron and J Vinatier for helpful comments. This work was supported by Inserm (MNB, BG, MPM) and by NIH MH 53631 and DA12242 (JMM). SW was the recipient of a fellowship from the 'Sociéte de Tabacologie'.

\section{REFERENCES}

Accili D, Fishburn CS, Drago J, Steiner H, Lachowicz JE, Park BH et al (1996). A targeted mutation of the D3 dopamine receptor gene is associated with hyperactivity in mice. Proc Natl Acad Sci USA 93: 1945-1949.

Adler LE, Olincy A, Waldo M, Harris JG, Griffith J, Stevens K et al (1998). Schizophrenia, sensory gating, and nicotinic receptors. Schizophr Bull 24: 189-202.

Barkley RA (2003). Issues in the diagnosis of attention-deficit/ hyperactivity disorder in children. Brain Dev 25: 77-83.

Barr AM, Lehmann-Masten V, Paulus M, Gainetdinov RR, Caron MG, Geyer MA (2004). The selective serotonin-2A receptor antagonist M100907 reverses behavioral deficits in dopamine transporter knockout mice. Neuropsychopharmacology 29: 221-228. 
Bernal MC, Vicens P, Carrasco MC, Redolat R (1999). Effects of nicotine on spatial learning in C57BL mice. Behav Pharmacol 3: 333-336.

Buccafusco JJ, Letchworth SR, Bencherif M, Lippiello PM (2005). Long-lasting cognitive improvement with nicotinic receptor agonists: mechanisms of pharmacokinetic-pharmacodynamic discordance. Trends Pharmacol Sci 26: 352-360.

Buisson B, Bertrand D (2002). Nicotine addiction: the possible role of functional upregulation. Trends Pharmacol Sci 23: 130-136.

Carboni E, Spielewoy C, Vacca C, Nosten-Bertrand M, Giros B, Di Chiara G (2001). Cocaine and amphetamine increase extracellular dopamine in the nucleus accumbens of mice lacking the dopamine transporter gene. J Neurosci 21: 1-4.

Cook Jr EH, Stein MA, Krasowski MD, Cox NJ, Olkon DM, Kieffer JE et al (1995). Association of attention-deficit disorder and the dopamine transporter gene. Am J Hum Genet 56: 993-998.

D'Hooge R, De Deyn PP (2001). Applications of the Morris water maze in the study of learning and memory. Brain Res Brain Res Rev 36: 60-90.

Di Chiara G, Bassareo V, Fenu S, De Luca MA, Spina L, Cadoni C et al (2004). Dopamine and drug addiction: the nucleus accumbens shell connection. Neuropharmacology 47: 227-241.

Diaz J, Pilon C, Le Foll B, Gros C, Triller A, Schwartz JC et al (2000). Dopamine D3 receptors expressed by all mesencephalic dopamine neurons. J Neurosci 20: 8677-8684.

DiMaio S, Grizenko N, Joober R (2003). Dopamine genes and attention-deficit hyperactivity disorder: a review. J Psychiatry Neurosci 28: 27-38.

Fernagut PO, Chalon S, Diguet E, Guilloteau D, Tison F, Jaber M (2003). Motor behavior deficits and their histopathological and functional correlates in the nigrostriatal system of dopamine transporter knock-out mice. Neuroscience 116: 1123-1130.

Gaddnas H, Pietila K, Piepponen TP, Ahtee L (2001). Enhanced motor activity and brain dopamine turnover in mice during long-term nicotine administration in the drinking water. Pharmacol Biochem Behav 70: 497-503.

Gainetdinov RR, Caron MG (2000). An animal model of attention deficit hyperactivity disorder. Mol Medicine Today 6: 43-44.

Gainetdinov RR, Jones SR, Caron MG (1999a). Functional hyperdopaminergia in dopamine transporter knock-out mice. Biol Psychiatry 46: 303-311.

Gainetdinov RR, Mohn AR, Caron MG (2001). Genetic animal models: focus on schizophrenia. Trends Neurosci 24: 527-532.

Gainetdinov RR, Wetsel WC, Jones SR, Levin ED, Jaber M, Caron MG (1999b). Role of serotonin in the paradoxical calming effect of psychostimulants on hyperactivity. Science 283: 397-401.

Gentry CL, Lukas RJ (2002). Regulation of nicotinic acetylcholine receptor numbers and function by chronic nicotine exposure. Curr Drug Targets CNS Neurol Disord 1: 359-385.

Gill M, Daly G, Heron S, Hawi Z, Fitzgerald M (1997). Confirmation of association between attention deficit hyperactivity disorder and a dopamine transporter polymorphism. Mol Psychiatry 2: 311-313.

Giros B, Jaber M, Jones SR, Wightman RM, Caron MG (1996). Hyperlocomotion and indifference to cocaine and amphetamine in mice lacking the dopamine transporter. Nature 379: 606-612.

Green MF (2006). Cognitive impairment and functional outcome in schizophrenia and bipolar disorder. J Clin Psychiatry 67: $36-42$.

Hsiao MC, Lin KJ, Liu CY, Tzen KY, Yen TC (2003). Dopamine transporter change in drug-naive schizophrenia: an imaging study with 99mTc-TRODAT-1. Schizophr Res 65: 39-46.

Keller JJ, Keller AB, Bowers BJ, Wehner JM (2005). Performance of alpha7 nicotinic receptor null mutants is impaired in appetitive learning measured in a signaled nose poke task. Behav Brain Res 162: $143-152$

Kem WR (2000). The brain alpha7 nicotinic receptor may be an important therapeutic target for the treatment of Alzheimer's disease: studies with DMXBA (GTS-21). Behav Brain Res 113: 169-181.

Krause KH, Dresel SH, Krause J, la Fougere C, Ackenheil M (2003). The dopamine transporter and neuroimaging in attention deficit hyperactivity disorder. Neurosci Biobehav Rev 27: 605-613.

Kumari V, Postma P (2005). Nicotine use in schizophrenia: the self medication hypotheses. Neurosci Biobehav Rev 29: 1021-1034.

Lai A, Parameswaran N, Khwaja M, Whiteaker P, Lindstrom JM, Fan $\mathrm{H}$ et al (2005). Long-term nicotine treatment decreases striatal alpha6* nicotinic acetylcholine receptor sites and function in mice. Mol Pharmacol 67: 1639-1647.

Le Foll B, Diaz J, Sokoloff P (2003). Increased dopamine D3 receptor expression accompanying behavioral sensitization to nicotine in rats. Synapse 47: 176-183.

Le Novere N, Corringer PJ, Changeux JP (2002). The diversity of subunit composition in nAChRs: evolutionary origins, physiologic and pharmacologic consequences. J Neurobiol 53: 447-456.

Levin ED (2002). Nicotinic receptor subtypes and cognitive function. J Neurobiol 53: 633-640.

Levin ED, Bradley A, Addy N, Sigurani N (2002). Hippocampal alpha7 and alpha4 beta2 nicotinic receptors and working memory. Neuroscience 109: 757-765.

Levin ED, Conners CK, Silva D, Canu W, March J (2001). Effects of chronic nicotine and methylphenidate in adults with attention deficit/hyperactivity disorder. Exp Clin Psychopharmacol 9: 83-90.

Levin ED, Conners CK, Sparrow E, Hinton SC, Erhardt D, Meck WH et al (1996). Nicotine effects on adult with attention deficit/ hyperactivity disorder. Psychopharmacology 123: 55-63.

Levin ED, McClernon FJ, Rezvani AH (2006). Nicotinic effects on cognitive function: behavioral characterization, pharmacological specification, and anatomic localization. Psychopharmacology 184: 523-539.

Levin ED, Rezvani AH (2002). Nicotinic treatment for cognitive dysfunction. Curr Drug Targets CNS Neurol Disord 1: 423-431.

Li D, Sham PC, Owen MJ, He L (2006). Meta-analysis shows significant association between dopamine system genes and attention deficit hyperactivity disorder (ADHD). Hum Mol Genet 15: 2276-2284.

Malin DH (2001). Nicotine dependence: studies with a laboratory model. Pharmacol Biochem Behav 70: 551-559.

Mansvelder HD, van Aerde KI, Couey JJ, Brussaard AB (2006). Nicotinic modulation of neuronal networks: from receptors to cognition. Psychopharmacology 184: 292-305.

Marks MJ, Whiteaker P, Collins AC (2006). Deletion of the alpha7, beta2, or beta 4 nicotinic receptor subunit genes identifies highly expressed subtypes with relatively low affinity for $\left[{ }^{3} \mathrm{H}\right]$ epibatidine. Mol Pharmacol 70: 947-959.

Martres MP, Bouthenet ML, Salés N, Sokoloff P, Schwartz JC (1985). Widespread distribution of brain dopamine receptors evidenced with $\left[{ }^{125} \mathrm{I}\right]$-iodosulpride, a highly selective ligand. Science 228: 752-755.

Maskos U, Molles BE, Pons S, Besson M, Guiard BP, Guilloux JP et al (2005). Nicotine reinforcement and cognition restored by targeted expression of nicotinic receptors. Nature 436: 103-107.

Mihailescu S, Drucker-Colin R (2000). Nicotine, brain nicotinic receptors and neuropsychiatric disorders. Arch Med Res 31: 131-144.

Moragrega I, Carrasco MC, Vicens P, Redolat R (2003). Spatial learning in male mice with different levels of aggressiveness: effects of housing conditions and nicotine administration. Behav Brain Res 147: 1-8.

Morice E, Billard JM, Denis C, Mathieu F, Betancur C, Epelbaum J et al (2007). Parallel loss of hippocampal LTD and cognitive flexibility in a genetic model of hyperdopaminergia. Neuropsychopharmacology (in press).

Morice E, Denis C, Giros B, Nosten-Bertrand M (2004). Phenotypic expression of the targeted null-mutation in the dopamine 
transporter gene varies as a function of the genetic background. Eur J Neurosci 20: 120-126.

Morice E, Denis C, Macario A, Giros B, Nosten-Bertrand M (2005). Constitutive hyperdopaminergia is functionally associated with reduced behavioral lateralization. Neuropsychopharmacology 30: 575-581.

Mugnaini M, Garzotti M, Sartori I, Pilla M, Repeto P, Heidbreder $\mathrm{CA}$ et al (2006). Selective down-regulation of [(125)I]Y(0)-alphaconotoxin MII binding in rat mesostriatal dopamine pathway following continuous infusion of nicotine. Neuroscience 137: 565-572.

Myers CS, Robles O, Kakoyannis AN, Sherr JD, Avila MT, Blaxton TA et al (2004). Nicotine improves delayed recognition in schizophrenic patients. Psychopharmacology 174: 334-340.

Nuutinen S, Ahtee L, Tuominen RK (2005). Time and brain region specific up-regulation of low affinity neuronal nicotinic receptors during chronic nicotine administration in mice. Eur J Pharmacol 515: 83-89.

Olincy A, Harris JG, Johnson LL, Pender V, Kongs S, Allensworth $\mathrm{D}$ et al (2006). Proof-of-concept trial of an alpha7 nicotinic agonist in schizophrenia. Arch Gen Psychiatry 63: 630-638.

Packard MG, Knowlton BJ (2002). Learning and memory functions of the Basal Ganglia. Annu Rev Neurosci 25: 563-593.

Pakkanen JS, Jokitalo E, Tuominen RK (2005). Up-regulation of beta2 and alpha7 subunit containing nicotinic acetylcholine receptors in mouse striatum at cellular level. Eur J Neurosci 21: 2681-2691.

Parish CL, Nunan J, Finkelstein DI, McNamara FN, Wong JY, Waddington JL et al (2005). Mice lacking the alpha4 nicotinic receptor subunit fail to modulate dopaminergic neuronal arbors and possess impaired dopamine transporter function. Mol Pharmacol 68: 1376-1386.

Parker SL, Fu Y, McAllen K, Luo J, McIntosh JM, Lindstrom JM et al (2004). Up-regulation of brain nicotinic acetylcholine receptors in the rat during long-term self-administration of nicotine: disproportionate increase of the alpha6 subunit. Mol Pharmacol 65: 611-622.

Pekonen K, Karlsson C, Laakso I, Ahtee L (1993). Plasma nicotine and cotinine concentrations in mice after chronic oral nicotine administration and challenge doses. Eur J Pharmac Sci 1: 13-18.

Perry DC, Kellar KJ (1995). [ $\left.{ }^{3} \mathrm{H}\right]$ epibatidine labels nicotinic receptors in rat brain: an autoradiographic study. J Pharmacol Exp Ther 275: 1030-1034.

Picciotto MR, Corrigall WA (2002). Neuronal systems underlying behaviors related to nicotine addiction: neural circuits and molecular genetics. J Neurosci 22: 3338-3341.

Pietila K, Ahtee L (2000). Chronic nicotine administration in the drinking water affects the striatal dopamine in mice. Pharmacol Biochem Behav 66: 95-103.

Pietila K, Salminen O, Leikola-Pelho T, Ahtee L (1996). Tolerance to nicotine's effects on striatal dopamine metabolism in nicotine-withdrawn mice. Eur J Pharmacol 318: 17-22.

Pontieri FE, Tanda G, Orzi F, Di Chiara G (1996). Effects of nicotine on the nucleus accumbens and similarity to those of addictive drugs. Nature 18: 255-257.

Purper-Ouakil D, Wohl M, Mouren MC, Verpillat P, Ades J, Gorwood P (2005). Meta-analysis of family-based association studies between the dopamine transporter gene and attention deficit hyperactivity disorder. Psychiatr Genet 15: 53-59.

Ralph RJ, Paulus MP, Fumagalli F, Caron MG, Geyer MA (2001). Prepulse inhibition deficits and perseverative motor patterns in dopamine transporter knock-out mice: differential effects of D1 and D2 receptor antagonists. J Neurosci 21: 305-313.

Rezvani AH, Levin ED (2001). Cognitive effects of nicotine. Biol Psychiatry 49: 258-267.

Sacco KA, Bannon KL, George TP (2004). Nicotinic receptor mechanisms and cognition in normal states and neuropsychiatric disorders. J Psychopharmacol 18: 457-474.
Schwartz JC, Diaz J, Bordet R, Griffon N, Perachon S, Pilon C et al (1998). Functional implications of multiple dopamine receptor subtypes: the D1/D3 receptor coexistence. Brain Res Brain Res Rev 26: 236-242.

Seth P, Cheeta S, Tucci S, File SE (2002). Nicotinic-serotonergic interactions in brain and behaviour. Pharmacol Biochem Behav 71: 795-805.

Sparks JA, Pauly JR (1999). Effects of continuous oral nicotine administration on brain nicotinic receptors and responsiveness to nicotine in C57Bl/6 mice. Psychopharmacology 141: 145-153.

Spielewoy C, Biala G, Roubert C, Hamon M, Betancur C, Giros B (2001). Hypolocomotor effects of acute and daily d-amphetamine in mice lacking the dopamine transporter. Psychopharmacology 159: 2-9.

Spielewoy C, Roubert C, Hamon H, Nosten-Bertrand M, Betancur C, Giros B (2000). Behavioral disturbances associated with hyperdopaminergia in dopamine-transporter knockout mice. Behav Pharmacol 11: 279-290.

Spurden DP, Court JA, Llyod S, Oakley A, Perry R, Pearson C et al (1997). Nicotinic receptor distribution in the human thalamus: autoradiographical localization of $\left[{ }^{3} \mathrm{H}\right]$ nicotine and $\left[{ }^{125} \mathrm{I}\right]-\alpha-$ bungarotoxin binding. J Chem Neuroanat 13: 105-113.

Stanwood GD, Artymyshyn RP, Kung M-P, Kung HF, Lucki I, McGonigle P (2000). Quantitative autoradiographic mapping of rat brain dopamine $\mathrm{D} 3$ binding with $\left[{ }^{125} \mathrm{I}\right] 7-\mathrm{OH}-\mathrm{PIPAT}$ : evidence for the presence of D3 receptors on dopaminergic and nondopaminergic cell bodies and terminals. J Pharmacol Exp Ther 295: 1223-1231.

Van Dam D, Lenders G, De Deyn PP (2006). Effect of Morris water maze diameter on visual-spatial learning in different mouse strains. Neurobiol Learn Mem 85: 164-172.

Vicens P, Carrasco MC, Redolat R (2003). Effects of early training and nicotine treatment on the performance of male NMRI mice in the water maze. Neural Plast 4: 303-317.

Vles JS, Feron FJ, Hendriksen JG, Jolles J, van Kroonenburgh MJ, Weber WE (2003). Methylphenidate down-regulates the dopamine receptor and transporter system in children with attention deficit hyperkinetic disorder (ADHD). Neuropediatrics 34: 77-80.

Waldman ID, Rowe DC, Abramowitz A, Kozel ST, Mohr JH, Sherman SL et al (1998). Association and linkage of the dopamine transporter gene and attention-deficit hyperactivity disorder in children: heterogeneity owing to diagnostic subtype and severity. Am J Hum Genet 63: 1767-1776.

Weiss S, Tzavara ET, Davis RJ, Nomikos GG, McIntosh JM, Giros B et al (2007). Functional alterations of nicotinic neurotransmission in dopamine transporter knock-out mice. Neuropharmacol (in press).

Whiteaker P, McIntosh JM, Luo S, Collins AC, Marks MJ (2000). 125I-alpha-conotoxin MII identifies a novel nicotinic acetylcholine receptor population in mouse brain. Mol Pharmacol 57: 913-925.

Wilens TE, Biederman J, Spencer TJ, Bostic J, Prince J, Monuteaux MC et al (1999). A pilot controlled clinical trial of ABT-418, a cholinergic agonist, in the treatment of adults with attention deficit hyperactivity disorder. Am J Psychiatry 156: 1931-1937.

Wonnacott S (1997). Presynaptic nicotinic ACh receptors. Trends Neurosci 20: 92-98.

Young JW, Crawford N, Kelly JS, Kerr LE, Marston HM, Spratt C et al (2007). Impaired attention is central to the cognitive deficits observed in alpha7 deficient mice. Eur Neuropsychopharmacol 15: 145-155.

Young JW, Finlayson K, Spratt C, Marston HM, Crawford N, Kelly JS et al (2004). Nicotine improves sustained attention in mice: evidence for involvement of the alpha7 nicotinic acetylcholine receptor. Neuropsychopharmacology 29: 891-900.

Zoli M, Lena C, Picciotto MR, Changeux JP (1998). Identification of four classes of brain nicotinic receptors using beta 2 mutant mice. J Neurosci 18: 4461-4472. 